\title{
ARTICLE
}

\section{Varieties of Inclusionary Populism? SYRIZA, Podemos and the Five Star Movement}

\author{
Nuria Font ${ }^{1}$, Paolo Graziano ${ }^{2 \star}$ and Myrto Tsakatika ${ }^{3}$ \\ ${ }^{1}$ Nuria Font, Department of Political Science and Public Law, Universitat Autònoma de Barcelona, \\ Barcelona, Spain, ${ }^{2}$ Paolo Graziano, Department of Political Science, Law and International Studies, \\ University of Padua, Padua, Italy, and ${ }^{3}$ Myrto Tsakatika, School of Social and Political Sciences, University \\ of Glasgow, Glasgow, UK \\ ${ }^{*}$ Corresponding author. Email: paoloroberto.graziano@unipd.it
}

(Received 14 August 2018; revised 7 March 2019; accepted 15 March 2019; first published online 8 May 2019)

\begin{abstract}
Over the past years, parties often described as populist, such as SYRIZA in Greece, the Five Star Movement (FSM) in Italy and Podemos in Spain have made significant electoral breakthroughs, unsettling well-established party systems. In the literature, inclusionary populism has primarily been applied to Latin America whereas the three Southern European parties have been examined individually, but not in comparative perspective. The purpose of this article is to provide a comparative analysis, based on an original electoral manifestos content analysis, aimed at unveiling the 'inclusionary populism' features of the 'new' political parties that have emerged in Southern Europe. By focusing on the 2012-16 period, the article shows that the inclusionary category can be fruitfully applied also to European political parties; it finds different degrees of inclusionary populism (namely between SYRIZA and Podemos); and it proves that the FSM falls between the two exclusionary vs. inclusionary poles.
\end{abstract}

Keywords: inclusionary populism; Southern Europe; SYRIZA; Podemos; Five Star Movement

According to Richard Katz and Peter Mair's (1995) 'cartel party' thesis, postindustrial economic transformation and technological advances have led to a shift of European political parties away from their representative function. The mediatization of politics, the decline of party membership (van Biezen et al. 2012) and the loosening of ties between parties and their affiliated organizations (Bale and Allern 2012) have resulted in the erosion of parties' institutional milieux to a significant extent. In response, political discontent with political parties has risen, as expressed in declining levels of institutional trust, the rise of anti-party sentiments (Poguntke and Scarrow 1996) and the emergence of populist attitudes in voters (Akkerman et al. 2013) and social movements as alternative political actors (Mudde 2004). Against the background of widespread popular discontent with mainstream political parties, adopting a populist discourse and mobilization 
strategy favours parties that are excluded from the 'cartel' and aim to challenge it from the outside. It is hence no surprise that Europe is witnessing the emergence of populist political actors whose discourse is of the people and whose declared aim is to break the mould.

While these long-term structural factors prepared the ground for the emergence of populist parties in Europe, it was contingent factors such as the Great Recession that contributed to bolstering their electoral success. In Southern Europe, the intensity of the economic crisis placed European political systems under strain by exacerbating the perception of inefficiency, widespread corruption and programmatic collusion of the mainstream parties that make up the 'cartel', thus increasing political discontent (Salgado and Stavrakakis 2018). In Northern Europe, where the effects of the economic crisis were not as profound as in the South, the opportunity to capitalize on popular concerns generated by calls for pan-European redistributive policies and trans-European migration was seized by populist political entrepreneurs, who attacked mainstream political parties for putting the interests of 'foreigners' before those of the native population. Populist parties have hence emerged as serious contenders for power across the continent after the crisis, challenging established party systems (Kriesi 2014; Verney and Bosco 2013).

In order to disentangle the populist crowded and somewhat dissonant world, scholars have distinguished between exclusionary and inclusionary populist parties (Mudde and Rovira Kaltwasser 2013). Whereas exclusionary populism has been largely investigated, inclusionary populism in Europe is a recent phenomenon that has not yet been sufficiently explored either in theoretical or empirical terms in comparative perspective. Hence, our main research questions: Does the inclusionary populist category accurately capture recent developments in Europe's South? If so, what are the differences between inclusionary populist discourses? In this study we are primarily interested in testing the heuristic validity of binary classifications of populism such as the inclusionary-exclusionary classification and, more specifically, exploring the possibility that the differences between populisms may be better captured not via dichotomous approaches but rather gradational ones (Caiani and Graziano 2016). Further, the article explores whether inclusionary populist parties in Southern Europe reflect Cas Mudde's (2004) homogeneous representation of 'the people'.

Our study focuses on a comparison of the three most electorally successful populist contender parties in Southern Europe over the post-crisis period: SYRIZA, the Five Star Movement (FSM) and Podemos. The main goal is exploratory: drawing on insights from in-depth comparative explorations of the three case studies, we aim to develop a sophisticated understanding of the concept of inclusionary populism in the European context. Our ambition is to set the groundwork and generate insights that will inform larger comparative studies of the inclusionary populist phenomenon.

The article is structured as follows. The first section presents the theoretical debates in which the article is grounded and the main questions addressed in the study. This is followed by the description of the data and methods employed in the comparative analysis. The subsequent three sections deal with the new populist contenders of Southern Europe. The section that follows analyses the results from a comparative perspective. The article concludes with a discussion of the main findings and a reflection on further research on inclusionary populism in Southern Europe and beyond. 


\section{The analytical framework: exclusionary vs. inclusionary populism}

Populism is widely understood as an ideology, albeit a 'thin-centred' ideology (Mudde 2004), because its core can be combined with other ideologies such as liberalism or communism. A variation on the understanding of populism as a 'thin ideology' is populism as a style or discourse of politics - that is, not expressing core beliefs but a mode of political expression employed strategically by its proponents (Kriesi and Pappas 2015). Mudde's well-established minimal definition of populism is that of 'an ideology that considers society to be ultimately separated into two homogeneous and antagonistic groups, "the pure people" versus "the corrupt elite", and which argues that politics should be an expression of the volonté générale (general will) of the people' (Mudde 2004: 543).

Mudde's definition has recently been challenged on the grounds that populists do not deploy a 'homogeneous' conception of the people (de Cleen et al. 2018; Katsambekis 2016; Stavrakakis and Jäger 2018; Stavrakakis 2017; Stavrakakis et al. 2017). Rather, it is argued, populists are actively engaged in constructing their 'people', by appealing to a wide array of groups, interests and identities, brought together in what Ernesto Laclau and Chantal Mouffe (2001) term 'a chain of equivalence'. This article concurs and builds on these objections by exploring the discursive politics that populists regularly engage in which involve the inclusion or exclusion of particular social groups and identities (outgroups) into/from 'the people'. We expect that the strategic choices populist actors make in this respect are vital when it comes to identifying the type of populism with which they can most closely be identified.

Comparative studies of populism have drawn a key distinction between inclusionary and exclusionary populism (Mudde and Rovira Kaltwasser 2013), a distinction which is based on three analytical dimensions originally applied to the analysis of the Israeli populist right: material, political and symbolic (Filc 2010: 128-138). The material dimension concerns the distribution of resources among social groups, with inclusionary populist parties in favour of mass welfare programmes to include the poor, and exclusionary populisms defending forms of welfare chauvinism that aim to protect established welfare insiders from immigrant outsiders. The political dimension refers to forms of political mobilization that go beyond representative democratic channels such as plebiscitary and local forms of radical democracy. Inclusionary populisms mean for these mechanisms to give a voice to disregarded groups while exclusionary populisms advocate similar devices but demand the disenfranchisement of immigrant groups. Finally, the symbolic dimension involves setting the boundaries of 'the people', with inclusionary movements highlighting, for instance, the 'dignity' of indigenous populations, while symbolic exclusion often draws on forms of cultural discrimination. In what follows we will adopt this analytical distinction, applying it to three largely successful populist parties in Southern Europe.

While exclusionary populism in Europe is associated with the far right, antiimmigration parties that have emerged or evolved since the 1980s (Kitschelt 1997; Norris 2005), inclusionary populism can be primarily associated with social democratic parties, as well as with parties of the radical left, beyond social democracy (Mouffe 2018). 'Left' is here understood as egalitarian, anti-capitalist and internationalist (March 2011). This type of populism is new to Europe's radical left 
politics (Stavrakakis and Katsambekis 2014). Luke March and Cas Mudde (2005) spoke of an ideological 'mutation' in the radical left party family in Europe that was leading parts of it to shift away from traditional Marxist-Leninist class analysis towards the emergence of a new left 'social-populism' (see also March 2011). It might prima facie be expected that inclusionary and exclusionary populisms overlap, respectively, with left and right populisms, or rather, that the inclusionaryexclusionary distinction can be subjugated to the left-right distinction when it comes to populist parties. While this expectation is reasonable, we do not make it our starting point in this study. Our concern is that an increasing number of populist parties self-identify as 'beyond' conventional (left-right) party politics while adopting a wide range of positions on the question of inclusion and exclusion. Under such circumstances we would argue that starting from the inclusionary-exclusionary distinction potentially carries greater explanatory strength than starting from the left-right distinction when it comes to classifying (South European) populisms.

Put differently, left and right are increasingly difficult to capture analytically, and the relatively novel distinction between 'exclusionary' and 'inclusionary' seems to be more in line with current political discourses and more in line with operationalization concerns when focusing on party manifestos. This does not imply that the difference is always straightforward, but rather that basing the distinction on three clear analytical dimensions allows a better understanding of the differences among different types of populist parties.

\section{Data and methods}

This study's primary task is to investigate whether and to what extent the discourses of the three most successful new parties in Southern European politics commonly portrayed as populist - SYRIZA, the FSM and Podemos - are inclusionary in nature. We selected these parties according to the following criteria. First, studies analysing the emergence of these parties commonly find that they display populist features (Kioupkiolis 2016; Kriesi and Pappas 2015; Passarelli and Tuorto 2018; Ramiro and Gómez 2017). Second, all three parties have experienced rapid electoral success and challenged and transformed their respective party systems. Finally, regardless of the fact that some party leaders have avoided identifying with left or right, expert surveys have identified these parties' ideological positions as traditional left/centre-left. In particular, the 2014 Chapel Hill Expert Survey indicates that they hold left/centre-left ideological positions (SYRIZA $=2, F S M=4.67$ and Podemos $=1.67$ ), on a 0 to 10 scale on the left-right axis (Polk et al. 2017). By comparing cases of parties labelled as populist, keeping the geographic region, the position in the party system and the estimated party positioning relatively constant, we are in a good position to characterize where these parties stand with regards to inclusionary populism.

The study combines quantitative text analysis of party manifestos with qualitative content analysis of manifestos and speeches, covering the 2012-16 period. The advantages of combining quantitative and qualitative text analysis in the study of populism have already been signalled in the literature on populism (Rooduijn and Pauwels 2011). Our approach involves a two-step process. 
In the first stage, we relied on a dictionary-based analysis of party manifestos to perform word counts. Word counts served to detect inclusionary elements in party manifestos and measure the extent to which manifestos attach importance to the inclusion of groups in society that suffer discrimination in the context of welfare schemes, political rights and group identity (outgroups). In this initial stage, automated content analysis would allow us to measure inclusionary populism, yielding exact and highly reliable results (Rooduijn and Pauwels 2011). The automated text analysis focused on electoral programmes as they are formal documents that include policy preferences and facilitate a reliable comparison. While analysing manifestos is sometimes considered to be insufficient to measure the degree of populism because, arguably, it does not capture well the people/elite dichotomy, it is important to highlight that this study does not purport to address this dichotomy but to conduct a systematic analysis of inclusionary elements in populist party discourses. We combine national and European party manifestos (see Table A1 in the online Appendix). ${ }^{2}$ The former refer to the most important electoral events in parliamentary systems, which allow citizens to elect their representatives in national assemblies and ultimately select their government. The analysis of the latter allows us to identify variations between the three parties in a single election. ${ }^{3}$

Partly based on Matthijs Rooduijn and Teun Pauwels's (2011) methodological approach, we generated a dictionary of inclusionary terms based on both theoretical and empirical criteria. Drawing closely on Cas Mudde and Cristóbal Rovira Kaltwasser's (2013) theoretical framework, we selected a limited range of words referring to key social groups (outgroups) that we would expect to see highlighted as worthy of inclusion in party discourses as well as terms related to principles, policies or procedures that would best reflect the three dimensions of the concept of inclusionary populism. The initial selection of terms contained words referring to such outgroups as well as to principles or policies aiming at improving the distribution of economic resources and welfare policies (material dimension), to institutional mechanisms and core principles that enhance outgroups' representation and political participation in the political system (political dimension), and to the idea of dignity and affirmation with the purpose of expanding the boundaries of the common identity (symbolic dimension). Table 1 includes the key features of inclusionary and exclusionary populism, on which the selection of terms is based. Once the terms were selected, we checked that the words appeared in the manifestos. Complementarily, we performed an empirically based selection of terms by adding context-specific words identified in the respective manifestos (Rooduijn and Pauwels 2011), for instance the Spanish word dependientes or the Greek term AMEA. ${ }^{4}$

The dictionary was initially elaborated in English and then translated into original languages, whereas context-specific terms were subsequently added in original languages. Word counts were performed automatically for FSM and Podemos manifestos in their original languages, and manually for SYRIZA manifestos in Greek and, as a double check, automatically on an own English translation. ${ }^{5}$ As we know from previous automated text analysis, dictionary-based analyses represent text as data and perform word counts to measure the extent to which documents belong to a particular category (Grimmer and Stewart 2013; Laver et al. 2003; Pauwels 2011; Rooduijn and Pauwels 2011; Slapin and Proksch 2008). We relied 
Table 1. Main Features of Inclusionary and Exclusionary Populism

\begin{tabular}{lll}
\hline $\begin{array}{l}\text { Type of populism/ } \\
\text { dimension involved }\end{array}$ & Inclusionary & Exclusionary \\
\hline Material & Welfare expansion & Welfare chauvinism \\
\hline Political & $\begin{array}{c}\text { Universal participation } \\
\text { expansion }\end{array}$ & $\begin{array}{c}\text { Selective participation } \\
\text { expansion }\end{array}$ \\
\hline Symbolic & $\begin{array}{c}\text { People/community } \\
\text { (encompassing definition) }\end{array}$ & $\begin{array}{c}\text { People/community } \\
\text { (restricted definition) }\end{array}$ \\
\hline
\end{tabular}

Source: Own elaboration based on Mudde and Rovira Kaltwasser (2013).

on this technique to measure the presence of each term in an accurate way, thus securing high levels of reliability (Aslanidis 2018; Rooduijn and Pauwels 2011). However, automated text analysis also raises validity concerns (Bonikowski and Gidron 2016; Grimmer and Stewart 2013; Rooduijn and Pauwels 2011). We took several validation steps.

To validate the dictionary and be confident that our measurement captures the concept under study (Adcock and Collier 2001; Rooduijn and Pauwels 2011), we manually checked the outcome of a first trial of the computerized analysis to eliminate the ambiguity problems often associated with word count approaches (Laver et al. 2003). Given that words may have different meanings in different languages and cultures, and that this might affect the results in a comparative analysis, we first checked that the majority of keywords contained in the dictionary - for example $\delta \eta \mu о \kappa \rho \alpha \tau i \alpha$, democrazia, democracia - share a core fundamental meaning across languages. Then, following a standard practice with automated text analysis, we exhaustively read the manifestos and identified whether each of the words encountered in the analysis had a univocal meaning and proceeded to remove false positives (Bonikowski and Gidron 2016). For instance, we only included the term 'community' when it referred to the idea of belonging to a group and discarded it when referred to the European Union (European Community). Likewise, the keyword 'culture' was removed when it referred to cultural policy rather to the notion of cultural identity. For similar reasons, the term 'nation' was maintained for the FSM but removed for SYRIZA and Podemos: for the latter, it is commonly used as a synonym for state-wide (e.g. national healthcare system) and not referring to the notion of national identity or community. The terms contained in the dictionary are reported in Table A2 in the online Appendix.

In order that we could be confident about the content validity of our analysis, we manually verified whether or not each of the associations between references to key outgroups and references to the dominant frames of each of the three dimensions of populism identified through the quantitative analysis expressed an inclusionary idea. For instance, we checked whether manifestos promote the involvement of immigrants in the welfare system, institutional participative arrangements and group identity, or otherwise.

It must be noted that manifestos vary considerably in size, with those of Podemos being much longer than those of SYRIZA and the FSM. While variations in text length may reflect differences in the degree of detail of policy proposals, we do not assume that size differences involve differences in the degree of inclusionary 
populism. ${ }^{6}$ That said, given that percentages for each keyword would be lower in longer, more detailed manifestos, and that this could lead us to misleading interpretations, the results are expressed both in relative and absolute numbers in Table A3 in the online Appendix. Figures A1 and A2 in the online Appendix graphically illustrate the word counts for each party as well as the disaggregated word counts by outgroups for each election, respectively.

The automated text analysis was complemented with a qualitative content analysis. We manually examined party manifestos to complement the findings of the computerized analysis. Key inclusionary ideas contained in manifestos - or the absence of them - were detected and are reported in the empirical section. Finally, the analysis of manifestos was triangulated with a qualitative content analysis of key speeches by party leaders. This served to nuance and better qualify the nature of the associations between outgroups and the three dimensions of inclusionary populism. The sample of speeches was selected based on several criteria. First, we selected speeches that are politically relevant for parties themselves, taking into account that they express in relative detail the ideological basis of the party and constitute landmarks in the history of party discourse. More specifically, we selected speeches which were given in highly symbolic (such as the New Year's Eve speech by Beppe Grillo) or institutional moments (such as the speech for the election of the president of the European Parliament by Pablo Iglesias). By selecting such politically relevant speeches, we could be more confident that they are globally representative of the party discourse - at least in the period under scrutiny (2012-16). Searches in parties' websites as well as additional documentary material served to identify relevant speeches. Second, we only selected speeches made by each of the main party leaders - Alexis Tsipras (SYRIZA), Beppe Grillo (FSM) and Pablo Iglesias (Podemos) - as they are in the best position to reflect their respective party discourse. Finally, the speeches selected (12 in total) were given during the period covered in this study - 2012-16 (see list of speeches in the reference section). In the empirical section, short fragments of speeches are included to qualitatively illustrate our findings. ${ }^{7}$

\section{Empirical results \\ SYRIZA}

SYRIZA was established in 2004 as an electoral and political coalition that brought together Synaspismos, a small party of democratic socialism of Eurocommunist heritage, and a number of other much smaller groups of the extra-parliamentary left of Maoist, Trotskyist, communist, ecologist, socialist and left social democratic origins. The coalition transformed itself into a unified political party immediately after the May 2012 national elections in Greece (Tsakatika and Eleftheriou 2013). In the midst of the complete overhaul of the political system that the economic crisis triggered in Greece, SYRIZA has been the main protagonist. Within the space of six years, SYRIZA went from being a minor party of the opposition barely crossing the $3 \%$ nationwide threshold required for parliamentary representation in the 2009 elections, to become a main party of government in the elections of January 2015 (see Table A1 in the online Appendix). 
SYRIZA's electoral success can be associated with its populist transformation, a relatively new development in the evolution of the party (Stavrakakis and Katsambekis 2014: 127). SYRIZA's populist discourse was not constitutive of its founding in 2004. Rather, it emerged as a prominent feature of the party's appeal during the socially and politically tumultuous period between 2010 - when the first 'bailout' agreement (and associated Memorandum of Understanding) was signed with Greece's creditors - and 2012, when the dual elections of May and June reordered Greek politics, elevating SYRIZA to the main opposition party. This was a time when SYRIZA tried to broaden its electoral appeal by attempting to voice the claims of emerging social movements such as the Indignados and 'Can't Pay, Won't Pay', among others, as well as by directly addressing disaffected voters who were distancing themselves primarily from PASOK, the main social democratic party. We will take SYRIZA's 'populist phase', analysed in this study, to extend at least until 2015 when the party won national elections twice, securing its electoral gains and its presence in government (Tsakatika 2016).

The main task in this section is to explore where SYRIZA's populism stands with regard to the distinction between inclusionary and exclusionary populism, focusing on the 2012-15 period. We can see clearly in Table A3 in the online Appendix that SYRIZA explicitly and systematically refers to workers, women, the unemployed, the young, immigrants and the poor as outgroups. Further, it is clear that 'welfare' and 'rights' are the words most frequently used in SYRIZA's manifestos with regard to the material dimension, 'democracy' and 'protest' are most used with regard to the political dimension while 'the people' (often referred to as 'our people') is most commonly used as a reference point in terms of the symbolic dimension (see Table A3 in the online Appendix).

A qualitative analysis of the manifestos is subsequently conducted, the aim of which is to identify associations between references to key outgroups and references to the dominant frames of each of the dimensions of populism identified through the quantitative analysis. We corroborate the data collected from the study of the manifestos with evidence from significant speeches by the party leader in order to clarify further the nature of those associations.

With regard to the material dimension, building a modern, universal welfare state and an economy where worker control and participation in economic decisions are central priorities in SYRIZA's manifestos. Labour rights, universal public provision of health and education accessible to all and special provisions to extend such provision to vulnerable groups such as immigrants, older people, disabled people and poorer people feature prominently. Describing SYRIZA's vision for a 'New Greece', Tsipras demands 'that everyone has the right to a minimum guaranteed dignified income. That everyone has access to dignified health care in public hospitals. That all retirees have a dignified pension and a minimum of care and social protection. That no child goes to school hungry' (Tsipras 2012b).

An inclusionary discourse is used each time reference is made to outgroups with welfare and rights. For Tsipras, SYRIZA's victory would be a victory for all those excluded from social protection: 'For each unemployed person, every person in despair, every hungry child, every patient who is experiencing the callousness of the inhuman State. For each retired person dying a slow death, every young person 
who seeks a new life in emigration, every citizen who sees his homeland bleed' (Tsipras 2014a).

In his speech presenting the candidates for the 2014 election, Tsipras makes a special appeal to the young: 'I want to address in particular the young. ... Fight the system that wants you without rights. Without hope. Without wages and insurance. Without education and health' (Tsipras 2014b). In the case of immigrants/ refugees there is a clear argument for policies to treat them 'humanely', as well as policies of inclusion in terms of 'equal political and social rights'.

Coming to the political dimension, while 'democracy' is the term most often used, references to participative, plebiscitary or other direct forms of democracy - often characteristic of inclusionary populist parties' discourses - are hardly mentioned in SYRIZA's manifestos. However, under the 'protest' category there are frequent mentions of 'the Movement' and of 'the movements' (see Table A3 in the online Appendix) in the 2014 European election manifesto. The implication is that movements are alternative (non-institutionalized) channels through which citizens participate more directly in the political process, and this is a channel that SYRIZA encourages and adopts. There is no specific mention of excluding specific groups from either direct democratic or representative forms of political participation. On the contrary, there are several references to improving female political representation and all of the key outgroups are urged to become active political participants. For instance, in a speech given in the most populous working-class neighbourhood of Athens, Peristeri, in January 2012, Tsipras mentions: 'None of them (the government, the Troika) is going to care about the life and the dignity of the workers, the unemployed, the pensioners, the young. None of them will care about our rights. We ourselves, are the only ones who can and who must defend them through social struggles' (Tsipras 2012a).

Coming to the symbolic dimension, the most frequent category is by far that related to 'the people', from which none of the outgroups are excluded. The construction of community primarily in national terms (where the community is referred to as 'the people', what is implied is 'the Greek people') does not entail the exclusion of immigrants. Rather, integration in the community is the preferred path. Characteristically, SYRIZA actively promoted the extension of citizenship rights to immigrants. In his maiden speech to parliament as prime minister, Tsipras announced a new immigration policy whose aim would be integration, protection, respect for human rights and the strengthening of social cohesion' (Tsipras 2015). In particular, one of the immediate priorities of the first SYRIZA government in February 2015 was to legislate on granting Greek citizenship rights to second-generation immigrants, people born in Greece of immigrant parents, who had been until then excluded from consideration and often lacked any formal citizenship. Criticizing the absence of a legal framework for granting Greek citizenship rights to second generation immigrants, Tsipras condemned the exclusion of: 'The most integrated section of immigrants, those young people who have linked their life and their education with our country, those young people who have learned no other language, have no other homeland and have only received a Greek education' (Tsipras 2015).

To summarize, SYRIZA's populism is clearly egalitarian and inclusionary. The party's aim is to include key outgroups such as workers, women, the unemployed, 
the poor, the young and immigrants in the development of a universal welfare state, in the formal extension of (and the substantive empowerment to use) political rights and in the community.

\section{The Five Star Movement}

Today the FSM is a well-established phenomenon in the Italian political landscape, especially after the 2018 elections. In the 2013 national elections, the European political world realized that Grillo's FSM (Beppe Grillo, as may be well known, is a former comedian and founder of the movement) was a new political entity which represented roughly over one-quarter of Italian voters (see Table A1 in the online Appendix). These results made the FSM the winner of the elections. A year later, at the European elections, the results were still quite positive, although only one voter out of five voted for the FSM.

The FSM quickly emerged as a new political actor gaining visibility in the 2012 local elections. The 'movement' - which has turned into a very loosely organized party - has its roots in Beppe Grillo's blog created in 2005 and, more generally, Grillo's career as a comedian who since the mid-1990s produced shows which were increasingly politically engaged. But what kind of a movement/party is the one created by Grillo? Currently, there is a general consensus among Italian scholars in considering Grillo's movement as a populist one (among others, Lanzone and Woods 2015). Grillo himself comes to terms with the definition of populism and states quite clearly, in a post (which is the main form of communication of the FSM) that: 'the FSM is not a rightist nor a leftist phenomenon, it's on the side of the citizens. Proudly populist' (Grillo 2013).

The results of our quantitative analysis show that in respect of outgroups, the FSM makes reference to very general notions of 'nation' (i.e. nationals), community (members), persons, people, youth, Italians and representatives of the agricultural world. Unlike the other political actors studied in this article, no reference is made to workers, women or immigrants. The only specific outgroup identified is represented by young people.

In terms of the material dimension, both manifestos are very limited in their proposals. With the exception of a 'guaranteed unemployment benefit', redistributive issues are virtually absent. The main material focus is against banks, against monopolies, in favour of local producers, public administration cost containment proposals (such as the reduction of public managers' salaries) and a number of proposals regarding companies indexed in the stock exchange. Therefore, compared to the other cases there is no direct reference to 'equality', 'rights' or 'welfare' either in inclusionary, or in exclusionary terms.

With regard to the political dimensions, the FSM identifies political enemies rather than principles of political intervention. The political situation within the European Union is seen as a 'war' between an economic 'oligarchy' which follows a (German-based) doctrine based on a 'virtual' reality which does not consider the 'rights' of European citizens and the rest of the population. The abolition of the Fiscal Compact is the key target, and in terms of whether to remain in the euro or not the decision is left to an unspecified 'consultation' among citizens. The specific 'protest' feature is particularly evident in the political dimension since there are 
no shared political principles. In other words, the political goals are all defined in antagonistic terms, with the limited exception of the creation of a Mediterranean alliance aimed at creating an undefined common policy 'against' the financial oligarchy. In terms of the participation element, there is only some reference to the above-mentioned 'consultation' procedures which, if combined with the abundant use of the internet supported in other documents and practices (such as the parlamentarie: Bordignon and Ceccarini 2014: 55), can be seen as a way to support webbased participation.

Finally, with reference to the symbolic dimension, there is a clear definition of what 'them' is whereas the notion of 'us' remains quite vague. The main identification of 'us' is Italy (18 times), the 'nation' (14 times), and the FSM is linked to the 12 times the term 'movement' appears in the document analysis, whereas the notions of 'community', 'people' and 'citizens' are strongly associated to those who need to 'resist' against 'them' (the European Central Bank, the International Monetary Fund, the World Bank, the EU, other Italian parties, Germany, international financial actors, neoliberals).

Considering the same dimensions (material, political and symbolic components of inclusionary populism) from a qualitative perspective, we analyse the most important speeches of Grillo (the New Year speeches, which are explicitly meant to be antagonistic to the traditional speeches of the president of the Republic and started in 2005, the year the blog was launched).

In the 31 December 2010 speech a strong anti-establishment tone comes up front, the whole second part of the speech being against the Palazzo, the palace, where all the politicians are:

The palace will sink, no doubt about this. ... This political class has failed and has to go away before it gets too late. Citizens need to auto-organize themselves as it was the case after the fall of fascism ... The Five Star Movement $\ldots$ is an opportunity for change, enabling the entrance of the citizen as such into politics. (Grillo 2010)

Again, here is the notion of ordinary citizens ('we') against the 'palace' ('them'). Quite interestingly, very rarely (if ever) does the notion of 'people' come into the speeches by Grillo: an individualized notion, citizen, and a collective notion, citizens, lies at the heart of the rhetoric of the leader of the FSM.

The 31 December 2013 post, written after the great success in the 2013 national elections, is even clearer in terms of the overcoming of representative democracy and the identification of a set of enemies: 'The FSM is your last chance ... We are you. We have everyone against us ... Parties, newspapers, banks, TV, freemasonry, the ECB, lobbies' (Grillo 2013).

Of particular interest for both the material and symbolic dimension is the 2016 New Year speech, which is entitled 'Happy 2017 by Beppe Grillo: It will be the year of the Italian pride'. In the speech there is a direct reference to the relevance of the basic income, which is introduced after a brief discussion of the risks of a society where people will work less and less (Grillo 2016). Later in the speech, Grillo advocated 'Italian pride' by stating: 'We need to be proud to be the best, be proud because Italians are the best. We need to be proud because the Made in Italy [in 
English] appeals to the entire world. ... We are Italians, and I want to shout it for the first time. ... We are the best, and will prove it' (Grillo 2016).

The New Year speeches indicate support for an expanded form of welfare (via the minimum income scheme), the support for more participatory forms of democracy and the overcoming of the distinction between 'us' (the 'citizens') and the politicians, against 'them' (banks, newspapers, other political parties, etc.).

In sum, the FSM seems to have a limited number of inclusionary traits. With respect to all the dimensions, both the New Year speeches and the electoral manifestos demonstrate very limited signs of inclusion towards categories which go beyond 'nationals' and 'Italians'. Although the speeches put an emphasis on direct democracy and expansionary forms of welfare, these elements are strongly associated with 'the people' who share the language - Italian - and who are therefore seen as citizens. No direct mention is made of immigrants or marginalized people in inclusionary terms.

\section{Podemos}

Podemos emerged following the various social mobilizations that channelled the Spanish society's resentment towards austerity policies and the political regime in a context of deep economic recession, distrust of political institutions and crisis of representation (Alonso and Rovira Kaltwasser 2015; Bosch and Durán 2019; Kioupkiolis 2016; Sanders et al. 2017). Certainly, many of Podemos's founders had actively participated in the Indignados/15M protests in 2011 against cutbacks in social services, increasing poverty and political corruption, and had longstanding experience of political activism in associative movements and radical left-wing parties. Formally, Podemos was created in January 2014 as a citizen movement reacting against traditional political parties and mainstream politics, with the aim of launching a popular candidacy for the European Parliament election. Shortly after, Podemos was transformed into a political party. Against all predictions, Podemos obtained roughly $8 \%$ of the Spanish votes in the European election, thus becoming the fourth political force at the time. In the 2015 general election, Podemos and its regional, left-wing allies in Catalonia, Galicia and Valencia obtained $20.6 \%$ of the vote and became the third parliamentary political force. In the 2016 general election, Podemos, this time in coalition with the left-wing party Izquierda Unida and the regional alliances, reached $21 \%$ of the vote and remained as the third party in parliament (see Table A1 in the online Appendix).

Podemos has commonly been portrayed as a populist party, combining antielitist claims with a left-wing discourse (De Cleen et al. 2018; Kioupkiolis 2016; Rodríguez-Teruel et al. 2016). Regarding the question of inclusionary populism, our quantitative analysis shows that Podemos's manifestos promote the inclusion of the main outgroups identified in our study, with a preponderance of women and workers, followed by the poor, immigrants, young people, disabled people and the unemployed. On the other hand, taking the three main dimensions of inclusionary populism together, 'welfare', 'rights' and 'participation' are the keywords most often employed. In particular, 'welfare' and 'rights' receive the highest counts in all three manifestos in relation to the material dimension, with the keywords 'equality', 'justice', 'universal' and 'solidarity' also appearing a considerable 
number of times. With regard to the political dimension, 'participation' is by far the most mentioned keyword in national manifestos, followed by 'democracy' and 'representation'. Other than this, references to specific instruments of direct democracy such as 'referendum' and 'assembly' are far less frequent. Finally, in all three manifestos, keywords related to the symbolic dimension are less frequent than the material and political ones. 'Dignity' and 'people' are among the most frequent ones, followed by 'identity' and 'self-determination'.

Results from the qualitative discourse analysis go in line with the ones from the quantitative one. Content analysis of Podemos's manifestos reveals that the associations between outgroups and the three dimensions of populism present inclusionary features. Podemos adopts a vision of society in which different groups - for instance workers, the youth and immigrants - are considered to be victims of dominating political and economic elites. At the same time, the party emphasizes the necessity to safeguard universal welfare rights encompassing outgroups, which is equated with the fulfilment of human rights. By way of an example, the national election manifestos promote taking measures to guarantee universal access to education and healthcare, the right to work and the right to have a taxation system that is fair for middle classes and workers. Explicit mention is made of the extension of universal healthcare coverage to the immigrant population. In addition to manifestos, a core element of inclusionary populism - that is, the assurance of a universal rights system encompassing the deprived segments of society - is reflected in several of Iglesias's speeches. The one given in Puerta del Sol in October 2015 serves as illustration:

We seriously dream of a country where those who have been forced to leave can get a return ticket; a country where those who want to move ahead with a project may do so without having to depend on banks; a country where access to housing does not become a life sentence; a country where starvation wages disappear; a country where policies protect from exclusion and poverty. (Iglesias 2015)

Concerning the political dimension, 'participation', 'representation' and 'democracy', which are the most frequently used terms related to the political dimension in electoral manifestos, are often employed to affirm outgroups' political rights. Political participation and representation of outgroups in the political process are associated with the notions of human dignity and democratic quality. As an illustration, national election manifestos propose cultural activities promoting the participation of immigrant, Roma or disabled people and women in public life, ensuring equality of opportunities for children and teenagers as well as workers' participation in the management of large companies. In the case of immigrants, there is a clear argument in favour of improving their political rights. Key measures include the closure of detention centres for immigrants, the reduction of deadlines to acquire Spanish nationality, the flexibilization of residence permits and family reunification processes, as well as the recognition of voting rights to settled foreign residents. In a speech given in Puerta del Sol in 2015, Iglesias referred to the immigrant population in the following terms: 'Those migrant workers: nobody has the right to call them foreigners in Spain' (Iglesias 2015). 
As regards the symbolic dimension, workers, dependants, the poor and the evicted are the main outgroups for which the manifestos propose the adoption of measures ensuring decent living conditions. Self-affirmation of Southern countries in the European context is explicit in the 2014 European election manifesto, which criticizes 'those who have built the neoliberal and antidemocratic Europe' and proposes a revision of the Lisbon Treaty. While these concerns are hardly explicit in national election manifestos, a vision of society in which Southern countries are presented as the victims of the European political and economic elites is recurrent in party speeches. In the one given for the election of the president of the European Parliament, in July 2014, Iglesias stated that: 'In peripheral Europe the situation is tragic: our countries have almost become protectorates, new colonies, where powers that no one has elected are destroying social rights and threatening social and political cohesion in our societies' (Iglesias 2014).

To sum up, Podemos's populism can be depicted as highly inclusionary. It advocates for the expansion of material and political rights to key outgroups, whereas the symbolic dimension of inclusionary populism is less explicit in the party discourse.

\section{Varieties of inclusionary populism in Southern Europe}

This section engages in a comparative examination of each of the three dimensions of inclusionary populism across our cases, based on the quantitative and qualitative analyses conducted. It highlights variation and identifies the dimension/s along which it occurs.

As a starting point, and focusing on national elections, it can be argued that there is a pronounced difference between SYRIZA's and Podemos's explicit references to a wide range of similar outgroups - that is, groups that profit disproportionately less from the common resources and benefits that are up for distribution among 'the people' or are altogether excluded from that distribution - and the FSM's limited reference to one group only. In particular, the workers, women, the unemployed, the young, the poor, immigrants and disabled people are the groups most frequently mentioned by SYRIZA and Podemos. The FSM, on the contrary, only makes specific reference to young people. This means outright that there is much less clarity with regard to the FSM's position on the inclusionary-exclusionary continuum than there is with regard to the position of SYRIZA and Podemos. Exactly where SYRIZA and Podemos (and the FSM, to the extent that a position can be detected) lie on that continuum can be examined by looking at the three dimensions of populism: material, political and symbolic (see Table 2).

In terms of the material dimension, significant variation is observed between the three cases. More specifically, the emphasis on rights and equality by SYRIZA and Podemos is much stronger than that placed on these values by the FSM. The latter makes some reference to rights and universality but little reference to any of the other terms in our dictionary. What is more, in the qualitative analysis it becomes clear that SYRIZA and Podemos put forward a left/egalitarian and universalist welfare programme that aims to widen the range of income supplements, unemployment insurance, healthcare and social benefits and extend redistribution to all outgroups. Conversely, while the FSM declares that it would like to see greater redistribution via a universal income scheme, it describes the eligibility for that 
Table 2. Share of Keywords in Election Manifestos ( $\left.{ }^{\star} 1000\right)$

\begin{tabular}{|c|c|c|c|c|c|}
\hline & 2012 & 2013 & 2014 (EP) & 2015 & 2016 \\
\hline \multicolumn{6}{|l|}{ SYRIZA } \\
\hline Material & 21.4 & & 11.1 & 4.9 & \\
\hline Political & 11.7 & & 12 & 4.5 & \\
\hline Symbolic & 6.1 & & 3.8 & 1.9 & \\
\hline Total & 39.3 & & 26.9 & 11.3 & \\
\hline \multicolumn{6}{|l|}{ FSM } \\
\hline Material & & 1.6 & 1.2 & & \\
\hline Political & & 6.4 & 2.2 & & \\
\hline Symbolic & & 4.8 & 11.8 & & \\
\hline Total & & 12.8 & 15.2 & & \\
\hline \multicolumn{6}{|l|}{ Podemos } \\
\hline Material & & & 16.8 & 10.9 & 10.8 \\
\hline Political & & & 6.6 & 4.8 & 4.8 \\
\hline Symbolic & & & 2.4 & 1.2 & 1.2 \\
\hline Total & & & 25.7 & 16.9 & 16.9 \\
\hline
\end{tabular}

Source: Parties' manifestos.

scheme in terms of nation (Italians) or class (the middle classes) without explicitly differentiating among included or excluded groups. Welfare expansionism can be considered to be at the very core of inclusionary populism in the same way that welfare chauvinism clearly demarcates exclusionary populism. While SYRIZA and Podemos are clearly inclusionary populist parties, the FSM can be considered in more ambiguous terms.

The findings also suggest that there is an overall lower level of salience of the political dimension as seen in party manifestos compared to the material one, especially for Podemos and for SYRIZA in the 2012 election. In particular, while all three parties refer to participation as a valuable principle that should be encouraged, there are different emphases in the terms the three parties prefer to use in order to highlight how citizens should participate. SYRIZA and Podemos for instance highlight democracy while the FSM does not. SYRIZA frequently refers to protest, which is not the case for the other two parties. Where SYRIZA and Podemos emphasize representative forms of democracy and compatible forms of political participation such as elections and parliament, the FSM does not. This variation is not only confirmed but made more specific by the qualitative analysis. When it comes to the political dimension, SYRIZA stresses social movements and the parliamentary arena; Podemos is keen on direct democracy as well as social media; and the FSM promotes digital forms of citizen participation. Again, SYRIZA and Podemos both call for the full inclusion of outgroups in the political process, while the FSM is less specific, with the exception of youth, who are called to take their future into their own hands. From this point of view, SYRIZA and Podemos can again be characterized as 
inclusionary populist political parties while this is less clear for the FSM. The latter will not be considered exclusionary populist since it does not explicitly aim to exclude particular groups from political participation - a practice it holds dear. However, it may not be considered inclusionary either, since it does not mention particular outgroups in its programme of extending political participation.

The symbolic dimension is the most salient one for the FSM but the least relevant for SYRIZA and Podemos, as shown in Table 2. The FSM strongly emphasizes the idea of the nation and the idea of 'community', whereas Podemos makes some reference to the notion of identity. A patriotic tone is often struck both by SYRIZA, as seen in Alexis Tsipras's speeches, and by the leader of the FSM. The difference between the two parties is that the FSM does not specify whether or not outgroups are to be included in the 'community', defined primarily in national terms, while SYRIZA's more implicit national construction of community includes references that indicate the desire to include or integrate outgroups such as immigrants. 'Dignity' is a core value for SYRIZA and Podemos but it is not mentioned by the FSM. Interestingly, adding to recent research on 'transnational populism' (Moffitt 2017), we find that it is not just the FSM, but all three parties that make some reference to Southern Europe, signifying their opposition to the drift that the economic crisis opened in the continent, placing the South in a position of subordination with respect to the North - and Germany in particular. This idea is endorsed by Podemos's manifesto for the 2014 European election but is subsequently downplayed in the general election discourse.

Finally, data on the European election allow us to refine our findings. As shown in Table 2, both SYRIZA and the FSM change the emphasis given to the different dimensions of inclusionary populism depending on whether they concur for national or European elections. By contrast, Podemos is more consistent on the weight given to each issue across election types. Second, we also observe cross-party variations as regards the dimension of inclusionary populism emphasized in the European election: Podemos clearly prioritizes the material dimension, the FSM stresses the symbolic one while the material and political dimensions are equally important for SYRIZA. Overall, the analysis of the European election manifestos allows us to better identify variations in the ways the three parties under study incorporate inclusionary features.

Overall, among our three cases, SYRIZA and Podemos are clearly inclusionary along the material and political dimensions, although less explicitly inclusionary along the symbolic one. The FSM remains the most ambiguous of the three cases as it does not specify outgroups in general or refer to immigrants in particular, in contrast to both SYRIZA and Podemos, which are clearer in this respect. This finding is particularly relevant since it confirms one of the core arguments in the literature on populism type which states that a dichotomic reasoning does not help but rather that individual cases of populism should be considered in terms of a continuum between the inclusionary and exclusionary categories.

\section{Conclusion}

This study has made a two-fold contribution. In empirical terms we have put forward new evidence on the three most successful inclusionary populist parties to 
emerge in Southern Europe in the aftermath of the economic crisis: SYRIZA, the FSM and Podemos. The electoral success of these parties has led to significant change in established European party systems and highlights the emergence and dissemination of the inclusionary populist phenomenon across the world's regions.

In theoretical terms, having applied the framework of inclusionary populism to another part of the world, beyond Latin America, we have demonstrated its wider usefulness and potential for comparative research. Broadly speaking, especially in comparative terms, the distinction between inclusionary and exclusionary seems more focused and less ambiguous with respect to the notion of left and right quite different in its national variants. Furthermore, once populism is defined as 'thin-centred populism', it would seem quite difficult to add specifications which are strongly linked to 'hard' ideologies such as left and right. Theoretically, the various dimensions of analysis (symbolic, political and material) capture the most important elements of populism, rather than the classic economic and cultural left-right notions (as applied, for example, by Inglehart and Norris 2016).

In addition, in identifying significant variation among our three cases, not only in terms of degree (Caiani and Graziano 2016), but also in terms of substantive characteristics, we qualify and add nuance to a debate that assumes populist parties to be either inclusionary or exclusionary (Mudde and Kaltwasser 2013). Furthermore, our study contributes to theoretical debates on inclusionary populism as the findings contradict Mudde's (2004) homogeneous image of 'the people', adding to recent research emphasizing heterogeneity and plurality (Errejón and Mouffe 2016; Katsambekis 2016; Kioupkiolis 2016; Schoor 2017). Interestingly, our findings suggest that heterogeneity is framed differently in different parties. While SYRIZA and Podemos explicitly emphasize the inclusion of a wide array of similar outgroups, FSM only refers to one group. While debatable, as both an individual and a collective notion of the people are central in FSM's rhetoric, claims of homogeneity would also seem less consistent.

Our findings allow us to put forward some tentative ideas regarding the factors that could explain variation and suggest some potential research hypotheses that could inform larger comparative studies of inclusionary populism in future research. First, it seems that some populist parties make clear references to outgroups, such as SYRIZA and Podemos, while others, such as the FSM, less so. We might expect that the closer to ideological extremes, the clearer a populist party's position can be expected to be on the question of inclusion. Second, the material dimension is much more strongly prioritized by the two parties that lean towards the left of the ideological continuum, SYRIZA and Podemos. This would perhaps indicate that the closer a populist party is to the left of the ideological continuum, the greater its attention to material issues. Third, the articulation of the cultural unit to which the three populist parties address their appeal along the symbolic dimension differ, with some attributing greater importance to the nation and some not. We might expect this element to differ according to each party's legacy. Furthermore, the three parties' appeal to intra-European North-South inequalities reveals a claim to equal respect among nations that belong to the same cultural entity. It differs from the anti-colonialist discourses that characterize Latin American populism along the symbolic dimension which highlight a claim to equal respect that appeals to an external aggressor who does not belong to the 
same cultural entity. Hence, it could be expected that the way the symbolic elements of inclusionary populism are defined will be determined by historical factors and will be likely to differ between nations and across the world's regions.

Finally, our findings are relevant with respect to the ongoing research on populism for a number of reasons. First, although we do not focus on the determinants of populism and therefore our article is not testing specific hypotheses, it sheds new light on how current analytical lenses could be used. Second, it provides evidence of the different nature of Southern European populism which has so far not been done in a comparative perspective. Third, it shows how inclusionary and exclusionary populism - although very promising analytically - should be considered as opposite poles of a continuum rather than different categories of populism. Our research shows that, if properly operationalized, the gradational (and not binary, vis-à-vis exclusionary) use of the inclusionary populism concept may be very useful to capture specific features of new populist parties, whereas in other cases greater ambiguity may be found (as in the case of the FSM) and therefore it may be considered as sharing a few exclusionary and inclusionary traits and therefore being difficult to classify.

Supplementary information. To view the supplementary information for this article, please visit https:// doi.org/10.1017/gov.2019.17

\section{Notes}

1 We would like to thank a reviewer for pointing out this potential additional contribution of our study. 2 Note that the 2015 and 2016 manifestos are almost identical in size and content, as the respective elections were held about six months apart. We have decided to include them both to illustrate that the three dimensions of populism remain unaltered along the two elections.

3 While we cover a small number of texts, we reject performing more interpretivist approaches such as holistic grading (Hawkins 2009). First, the study is not focused on identifying or measuring populism, but on whether the populist discourse is of an inclusionary nature. Word counts are a first step for identifying and qualifying the associations between outgroups and the three inclusionary dimensions of inclusionary populism. Second, an automated word count combined with a content analysis of manifestos and speeches, rather than focusing on the tone or style of the manifesto as a whole, allows the topic under examination to be addressed better and yields sufficiently reliable results.

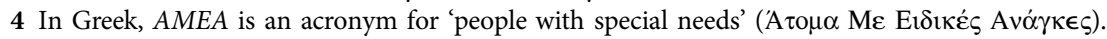

5 We opted for the automated word count of the English version of the SYRIZA manifesto as the software we employed, Yoshikoder, does not accept Greek characters.

6 Podemos's manifestos for the general elections contain around 52,500 words (annexes not included), compared to approximately 2,600 for SYRIZA and 2,400 for the FSM. For the European election, the word count is around 9,700 for Podemos, approximately 5,300 for SYRIZA and roughly 3,200 for the FSM. 7 Translations of fragments of speeches are our own.

8 While the speech was given before the study period, we include it to illustrate that the anti-establishment tone is present earlier.

\section{References}

Adcock R and Collier D (2001) Measurement Validity: A Shared Standard for Qualitative and Quantitative Research. American Political Science Review 25(3), 529-546.

Akkerman A, Mudde C and Zaslove A (2013) How Populist Are the People? Measuring Populist Attitudes in Voters. Comparative Political Studies 47(9), 1324-1453.

Alonso S and Rovira Kaltwasser C (2015) Spain: No Country for the Populist Radical Right? Southern European Society and Politics 20(1), 21-45. 
Aslanidis P (2018) Measuring Populist Discourse with Semantic Text Analysis: An Application on Grassroots Populist Mobilization. Quality and Quantity 52(3), 1241-1263.

Bale T and Allern EH (2012) Political Parties and Interest Groups: Disentangling Complex Relationships. Party Politics 18(1), 7-25.

Bonikowski B and Gidron N (2016) The Populist Style in American Politics: Presidential Campaign Discourse, 1952-1996. Social Forces 94(4), 1593-1621.

Bordignon F and Ceccarini L (2014) Protest and Project, Leader and Party: The Normalisation of the Five Star Movement. Contemporary Italian Politics 6(12), 54-72.

Bosch A and Durán I (2019) How Does Economic Crisis Impel Emerging Parties on the Road to Elections? The Case of the Spanish Podemos and Ciudadanos. Party Politics 25(2), 252-267.

Caiani M and Graziano PR (2016) Varieties of Populism: Insights from the Italian Case. Italian Political Science Review 46(2), 243-267.

De Cleen B (2017) Populism and Nationalism. In Kaltwasser CR, Taggart P, Espejo PO and Ostiguy P (eds), The Oxford Handbook of Populism. Oxford: Oxford University Press, pp. 342-362.

De Cleen B, Glynos J and Mondon A (2018) Critical Research on Populism: Nine Rules of Engagement. Organization 25(5), 649-661.

Filc D (2010) The Political Right in Israel: Different Faces of Jewish Populism. London: Routledge.

Errejon I and Mouffe C (2016) Podemos: In the Name of the People. London: Lawrence \& Wishart.

Grimmer J and Stewart BM (2013) Text as Data: The Promise and Pitfalls of Automatic Content Analysis Methods for Political Texts. Political Analysis 21(3), 267-297.

Hawkins KA (2009) Is Chávez Populist? Measuring Populist Discourse in Comparative Perspective. Comparative Political Studies 42(8), 1040-1067.

Inglehart R and Norris P (2016) Trump, Brexit, and the Rise of Populism: Economic Have-Nots and Cultural Backlash. Faculty Research Working Paper Series, RWP16-026.

Katsambekis G (2016) Radical Left Populism in Contemporary Greece: Syriza's Trajectory from Minoritarian Opposition to Power. Constellations 23(3), 391-403.

Katz RS and Mair P (1995) Changing Models of Party Organization and Party Democracy: The Emergence of the Cartel Party. Party Politics 1(1), 5-28.

Kioupkiolis A (2016) Podemos: The Ambiguous Promises of Left-Wing Populism in Contemporary Spain. Journal of Political Ideologies 21(2), 99-120.

Kitschelt H (1997) The Radical Right in Western Europe. Ann Arbor: University of Michigan Press.

Kriesi H (2014) The Populist Challenge. West European Politics 37(2), 361-378.

Kriesi H and Pappas TS (eds) (2015) European Populism in the Shadow of the Great Recession. Colchester: ECPR Press.

Laclau E and Mouffe C (2001) Hegemony and Socialist Strategy: Towards a Radical Democratic Politics. London: Verso.

Lanzone ME and Woods D (2015) Riding the Populist Web: Contextualizing the Five Star Movement (M5S) in Italy. Politics and Governance 3(2), 54-64.

Laver M, Benoit K and Garry J (2003) Extracting Policy Positions from Political Texts. American Journal of Political Science 97(2), 311-331.

March L (2011) Radical Left Parties in Europe. London: Routledge.

March L and Mudde C (2005) What's Left of the Radical Left? The European Radical Left After 1989: Decline and Mutation. Comparative European Politics 3(1), 23-49.

Moffitt B (2017) Transnational Populism? Representative Claims, Media and the Difficulty of Constructing a Transnational 'People'. Javnost - The Public 24(4), 409-425.

Mouffe C (2018) For a Left Populism. London: Verso.

Mudde C (2004) The Populist Zeitgeist. Government and Opposition: An International Journal of Comparative Politics 39(4), 542-563.

Mudde C and Rovira Kaltwasser C (2013) Exclusionary vs. Inclusionary Populism: Comparing the Contemporary Europe and Latin America. Government and Opposition: An International Journal of Comparative Politics 48(2), 147-174.

Norris P (2005) Radical Right: Voters and Parties in the Electoral Market. New York: Cambridge University Press.

Passarelli G and Tuorto D (2018) Five Star Movement: Purely a Matter of Protest? The Rise of a New Party Between Political Discontent and Reasoned Voting. Party Politics 24(2), 129-140. 
Pauwels T (2011) Measuring Populism: A Quantitative Text Analysis of Party Literature in Belgium. Journal of Elections, Public Opinion and Parties 21(1), 97-119.

Poguntke T and Scarrow SE (1996) The Politics of Anti-Party Sentiment: Introduction. European Journal of Political Research 29(3), 257-262.

Polk J, Rovny J, Bakker R, Edwards E, Hooghe L, Jolly S, Koedam J, Kostelka F, Marks M, Schumacher G, Steenbergen M, Vachudova M and Zilovic M (2017) Explaining the Salience of Anti-Elitism and Reducing Political Corruption for Political Parties in Europe with the 2014 Chapel Hill Expert Survey Data. Research and Politics 4(1), 1-9.

Ramiro L and Gómez R (2017) Radical-Left Populism During the Great Recession: Podemos and its Competition with the Established Radical Left. Political Studies 65(1S), 108-126.

Rodríguez-Teruel J, Barrio A and Barberà O (2016) Fast and Furious: Podemos' Quest for Power in Multi-Level Spain. South European Society and Politics 21(4), 561-585.

Rooduijn M and Pauwels T (2011) Measuring Populism: Comparing Two Methods of Content Analysis. West European Politics 34(6), 1272-1238.

Salgado S and Stavrakakis Y (2018) Introduction: Populist Discourses and Political Communication in Southern Europe. European Political Science, published early online, February, https://doi.org/10.1057/ s41304-017-0139-2.

Sanders K, Molina Hurtado MJ and Zoragastua J (2017) Populism and Exclusionary Narratives: The 'Other' in Podemos' 2014 European Union Election Campaign. European Journal of Communication 32(6), 522-567.

Schoor C (2017) In the Theatre of Political Style: Touches of Populism, Pluralism and Elitism in Speeches of Politicians. Discourse and Society 28(6), 657-676.

Slapin JB and Proksch S-O (2008) A Scaling Model for Estimating Time-Series Party Positions from Texts. American Journal of Political Science 52(3), 705-722.

Stavrakakis Y (2017) Discourse Theory in Populism Research. Journal of Language and Politics 16(4), 523-534.

Stavrakakis Y and Jäger A (2018) Accomplishments and Limitations of the 'New' Mainstream in Contemporary Populism Studies. European Journal of Social Theory 21(4), 547-565.

Stavrakakis Y and Katsambekis G (2014) Left-Wing Populism in the European Periphery: The Case of SYRIZA. Journal of Political Ideologies 19(2), 119-142.

Stavrakakis Y, Katsambekis G, Nikisianis N, Kioupkiolis A and Siomos T (2017) Extreme Right-Wing Populism in Europe: Revisiting a Reified Association. Critical Discourse Studies 14(4), 420-439.

Tsakatika M (2016) SYRIZA's Electoral Rise in Greece: Protest, Trust and the Art of Political Manipulation. South European Society and Politics 21(4), 519-540.

Tsakatika M and Eleftheriou C (2013) The Radical Left's Turn towards Civil Society in Greece: One Strategy, Two Paths. South European Society and Politics 18(21), 81-99.

van Biezen I, Mair P and Poguntke T (2012) Going, Going ... Gone? The Decline of Party Membership in Contemporary Europe. European Journal of Political Research 51(1), 24-56.

Verney S and Bosco A (2013) Living Parallel Lives: Italy and Greece in an Age of Austerity. South European Society and Politics 18(4), 397-426.

\section{Party documents}

Five Star Movement (2013) Un programma unico perché di tutti. Programma per le elezioni europee, www.beppegrillo.it/europee/programma.

Five Star Movement (2014) In Europa per l'Italia. Programma M5S, www.beppegrillo.it/europee/ programma.

Podemos (2014) PODEMOS. Documento Final del Programa Colaborativo, http://blogs.elpais.com/files/ programa-podemos.pdf.

Podemos (2015) Queremos, Sabemos, Podemos. Elecciones Generales. 20 December, https://lasonrisadeunpais.es/wp-content/plugins/programa/data/programa-es.pdf.

Podemos (2016) PODEMOS. 26J, https://lasonrisadeunpais.es/wp-content/uploads/2016/06/PodemosPrograma-Electoral-Elecciones-Generales-26J.pdf.

SYRIZA-United Social Front (2012) They Decided Without Us, We Are Proceeding Without Them. Election manifesto, April-May, www.syn.gr/ekl2012/eklogikidiak2012.pdf. 
SYRIZA (2014) For Radical Change in Greece and the Attainment of Another Europe. Manifesto for the 2014 European Elections. April, left.gr/news/i-diakiryxi-toy-syriza-gia-tis-eyroekloges.

SYRIZA (2015) Hope is on the Way. Greece is Moving Forward - Europe is Changing. A Framework Government Programme. January, www.syriza.gr/upload/60147_1.pdf.

\section{Speeches by party leaders}

Grillo B (2008) New Year Speech, www.beppegrillo.it/2008/12/discorso_di_capodanno.html.

Grillo B (2010) New Year Speech, www.beppegrillo.it/2010/12/messaggio_di_fi.html.

Grillo B (2012) New Year Speech, http://www.beppegrillo.it/2012/12/discorso_di_fin.html.

Grillo B (2013) New Year Speech, http://www.beppegrillo.it/2013/12/messaggio_di_fine_anno_2013_di_ beppe_grillo.html.

Grillo B (2013) Post on his personal website. December, www.beppegrillo.it/2013/12/il_m5s_e_populista_ ne_di_destra_ne_di_sinistra.html.

Grillo B (2014) New Year Speech, http://www.beppegrillo.it/2014/12/discorso_di_fine_anno_2014_di_ beppe_grillo_ioguardobeppe.html.

Grillo B (2016) New Year Speech, www.beppegrillo.it/2016/12/buon_2017_da_beppe_grillo_sara_lanno_ dellorgoglio_italiano.html.

Iglesias P (2014) Speech for the Election of the President of the European Parliament. 1 July, www.youtube.com/watch? $=$ =CJYQEGxXI-o.

Iglesias P (2015) Speech at Puerta del Sol, Madrid. 31 January, www.youtube.com/watch? $\mathrm{v}=\mathrm{y} 4 \mathrm{AvdOsZ7Mg}$.

Tsipras A (2012a) Speech at SYRIZA rally in Peristeri. 23 January, www.syriza.gr/article/id/45176.

Tsipras A (2012b) Speech at central election rally of SYRIZA/EKM in Athens, Omonia Square. 3 May, www.syriza.gr/article/id/46136.

Tsipras A (2014a) Speech at SYRIZA event 'Three Ballot Boxes, One Option: Victory!'. Athens, 17 February, www.syriza.gr/article/id/54871.

Tsipras A (2014b) Speech at the presentation of the SYRIZA list for the European Parliament. Athens, 29 April, www.avgi.gr.

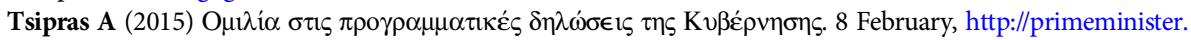
gr/2015/02/08/13322.

Cite this article: Font N, Graziano P, Tsakatika M (2021). Varieties of Inclusionary Populism? SYRIZA, Podemos and the Five Star Movement. Government and Opposition: An International Journal of Comparative Politics 56, 163-183. https://doi.org/10.1017/gov.2019.17 